\title{
RHEOLOGICAL PROPERTIES OF BRINE/VEGETABLE OIL/POLYETHOXYLATED NON- IONIC SURFACTANTS BASED MICROEMULSION
}

\author{
E. A. ARAÚJO ${ }^{1 *}$, F. D. S. CURBELO ${ }^{1 * *}$, A. I. C. GARNICA ${ }^{1}$, R. P. F. SOUSA ${ }^{1}$, E. A. ARAÚJO², G. S. BRAGA ${ }^{1}$, J. C. O. \\ FREITAS ${ }^{3}$ \\ ${ }^{1}$ Federal University of Paraiba, ${ }^{2}$ Federal University of Para, ${ }^{3}$ Federal University of Rio Grande do Norte \\ elayneaa7@gmail.com*, fabioladias@yahoo.com ${ }^{* *}$
}

Received 14/08/2017 - Accepted 07/03/2018

DOI: $10.15628 /$ holos.2018.6227

\section{ABSTRACT}

This study aimed to develop microemulsion through of ternary system composed of brine (aqueous phase), vegetable oil (oil phase), and non-ionic polyethoxylated surfactants, T20 and T80. From the ternary diagrams obtained, two systems were chosen in the regions of microemulsion (Winsor IV) and, subsequently, were conducted rheological study, at different temperatures, and cloud point studies of these systems. The results
\end{abstract}

showed that the microemulsion of $\mathrm{T} 20 /$ brine/vegetable oil presented thermal stability up to $53^{\circ} \mathrm{C}$ and microemulsions of $\mathrm{T} 80 / \mathrm{brine} /$ vegetable oil up to $72^{\circ} \mathrm{C}$, that could be due a change in micelle morphology and cloud point of each microemulsion system. The rheological results indicated non-Newtonian behavior, adjusted by Herschel - Bulkley model.

KEYWORDS: surfactant, microemulsion, phase diagram, rheology.

\section{PROPRIEDADES REOLÓGICAS DE MICROEMULSÕES A BASE DE SALMOURA/ÓLEO VEGETAL/TENSOATIVOS POLIETOXIADOS NÃO-IÔNICOS}

\section{RESUMO}

O estudo é destinado ao desenvolvimento de microemulsões através de sistemas ternários compostos de salmoura (fase aquosa), óleo vegetal (fase oleosa), e tensoativos polietoxilados não-iônicos, T20 e T80. A partir dos diagramas obtidos, foram escolhidos dois sistemas nas regiões de microemulsão (Winsor IV) e, posteriormente, foram realizados estudos reológicos, a diferentes temperaturas, e estudos de ponto de turbidez desses sistemas. Os resultados mostraram que a microemulsão de T20/salmoura/óleo vegetal apresentaram estabilidade térmica até $53{ }^{\circ} \mathrm{C}$ e a microemulsão de T80/salmoura/óleo vegetal de até 72 ${ }^{\circ} \mathrm{C}$ que poderia resultar de uma mudança na morfologia da micela e no ponto de turbidez de cada sistema de microemulsão. Os resultados reológicos indicaram comportamento não-newtoniano, ajustado pelo modelo de Herschel-Bulkley.

PALAVRAS-CHAVE: tensoativo, microemulsão, diagrama de fases, reologia. 


\section{INTRODUCTION}

Surfactants are amphiphilic molecules that have in the same molecule, polar or hydrophilic groups with affinity for water, and the nonpolar or hydrophobic groups with affinity for organic components, as for example, oil. Surfactants are surface-active agents. These molecules when are present in little concentration, in the system, have the property to adsorb on surfaces or interfaces and modify, significantly, the surface free energy or interfacial. While, in high concentrations forms a structure known as micelles (Lange, 1999).

Microemulsions are formed by two immiscible liquids, spontaneously one liquid dispersed in the other, and with presence of the surfactant, occurring the solubilizing of these components, making it the more stable inside the micellar structure than in solution or its original phase, allowing spontaneous formation of a microemulsion (Daltin, 2011).

It is well-known that the occurrence of a microemulsion demands a proper hydrophiliclipophilic balance (HLB) between the surfactant(s) and the physic-chemical environment. Each surfactant has a value quantitative of $\mathrm{HLB}$, which is a way of analyze the characteristics hydrophilic and hydrophobic of surfactant molecule in solution (Daltin, 2011 and Quintero, et al., 2011).

Microemulsion is a thermodynamically stable liquid phase. Depending on the phase behavior of the mixture, structures formed for microemulsions can be divided in three categories (Winsor, 1954; Reed and Healy, 1977). Winsor (1954) classified microemulsions containing oil, water, and surfactant as Type I, Type II, and Type III.

A Type I microemulsion (Winsor I) is an oil-in-water microemulsion (O/W) in equilibrium with an excess oil phase. A Type II microemulsion (Winsor II) is a water-in-oil microemulsion (W/O) in equilibrium with an excess water phase. A Type III microemulsion (Winsor III) is a bicontinuous systems that both components water and oil are disperses due the structures of surfactants in equilibrium with an excess oil phase and excess water phase (Daltin, 2011; Winsor, 1954). A singlephase microemulsion (Winsor IV - WIV) is formed when a sufficient amount of surfactant is added to solubilize the excess oil and water.

Microemulsion technology has been used in many areas due to its lower energy requirements. Thereby, microemulsions are also attracting the interest of researchers due to their potential as drug delivery vehicles, in other food and pharmaceutical applications, and in the petrochemical industry (Lee, 2011). Specifically, oil industry have various applications, including enhanced oil recovery (EOR), wellbore cleanup, and for general removal of formation damage (Karambeigi et al., 2016; Quintero et al., 2011; Quintero et al., 2009 and Quintero et al., 2007).

Thereby, this paper presents the rheological study of formulations positioned in an area of the phase diagram that correspond to maximum detergency and optimum interfacial properties required for field applications. The relationship between the fluid type and viscosity behavior, when submitted in different shear stress, in variations of temperature are discussed. 


\section{MATERIALS AND METHODS}

\subsection{Chemicals}

The chemicals used for prepare the microemulsion systems were: vegetable oil from pine (organic phase); brine (aqueous phase); nonionic surfactants of the Dynamic brand, polysorbate 20 (T20) and 80 (T80).

\subsection{Microemulsion systems}

To delimit the regions of microemulsions, has been necessary the construction of ternary phase diagram. These diagrams, composed of three components (aqueous phase, oil phase and nonionic surfactant), were obtained at temperature of $28^{\circ} \mathrm{C}$. As was used one nonionic surfactant, was not necessary the presence of the cosurfactant.

To determine the Winsor's regions in ternary phase diagram, aqueous phase was mixed with nonionic surfactant, in known mass fraction, and the mixture was titrated with oil phase. The titration with oil phase was performed until the appearance of cloud in the system, characterizing the appearance of a biphasic or three-phase system, according chance in the Winsor's regions.

The ternary phase diagram was constructed by plotting the mass fractions of aqueous phase, oil phase and surfactant used in experiment.

\subsection{Rheological study}

Rheological study was performed in Brookfield rheometer (LVDVIII-Ultra). The apparent viscosity measurements of microemulsion were obtained at temperature ranged from 30 to $70^{\circ} \mathrm{C}$, varying by intervals of $10^{\circ} \mathrm{C}$. This temperature range was used to verify the behavior of microemulsion at temperatures similar to oil reservoirs temperature, found in Potiguar Basin (Brazil), approximately $55^{\circ} \mathrm{C}$. The measurements were realized at each temperature, changing only the rotational speed between 0 to $90 \mathrm{rpm}$.

\subsection{Cloud point}

The solubility reduction is a limiting factor for the use of nonionic surfactants, either because of estheric effects (cloudiness or phase separation) or because their surfactant functions are reduced at higher temperatures. When the temperature increases, at a certain point, the behavior of an aqueous micelle solution of nonionic surfactant also changes, so that a cloud of insoluble surfactant appears in the solution. The temperature corresponding to cloud point was determined and verified visually, by the change of cloud of the solution when the sample was heated at a rate of about $1 \mathrm{o} / \mathrm{min}$ until it reached the cloud point temperature. The solutions were stirred and heated with a magnetic stirrer with temperature control (Figure 1). 


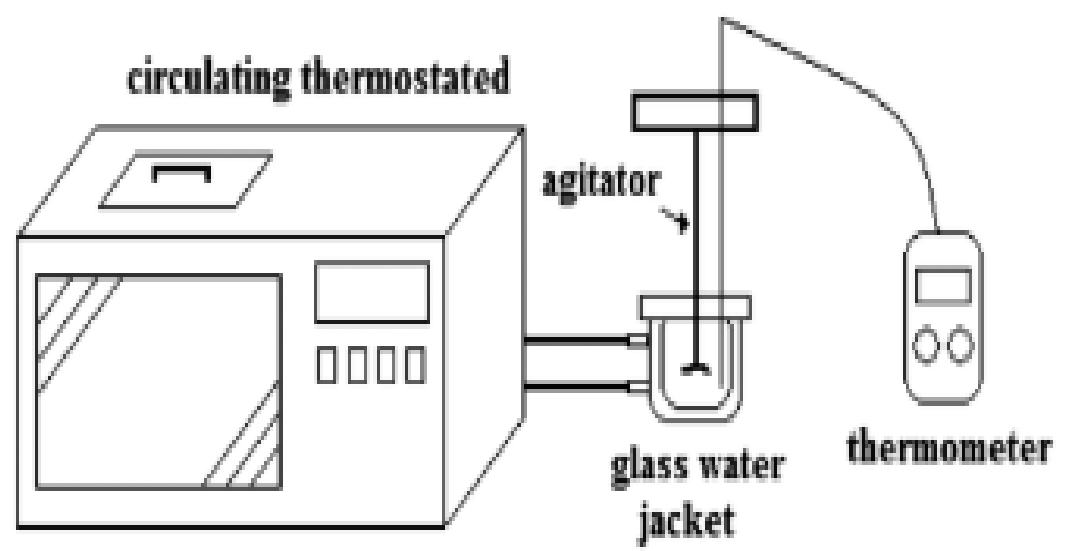

Figure 1: System used to determine cloud point.

\section{RESULTS AND DISCUSSION}

\subsection{Phase diagram}

Two phase diagrams were constructed to identify the Winsor's regions. In Figure 2, the system composed: brine, vegetable oil and surfactant (T20), it was observed the emulsion, WI, WII and WIV regions. In Figure 3, phase diagram was done with brine, vegetable oil and surfactant (T80), and it was observed the presence of emulsions, WI, WII, WIII and WIV regions.

In Figures 2 and 3, in phase diagrams were observed differences between the Winsor's regions that it can be associated to different surfactants used. The nonionic surfactants used are hydrophilic (with high HLB), and surfactants, $\mathrm{T} 20$ and T80, has as a molecular chain $\mathrm{C}_{58} \mathrm{H}_{114} \mathrm{O}_{26}$ and $\mathrm{C}_{64} \mathrm{H}_{124} \mathrm{O}_{26}$, respectively. The polymeric chain present in molecule has several oxygen atoms, with significant electronegativity and polar characteristic, making them soluble in water, which favors their application in oil in water microemulsion (O/A). The oil in water microemulsion $(O / A)$ was characterized by a liquid phase of appearance clear.

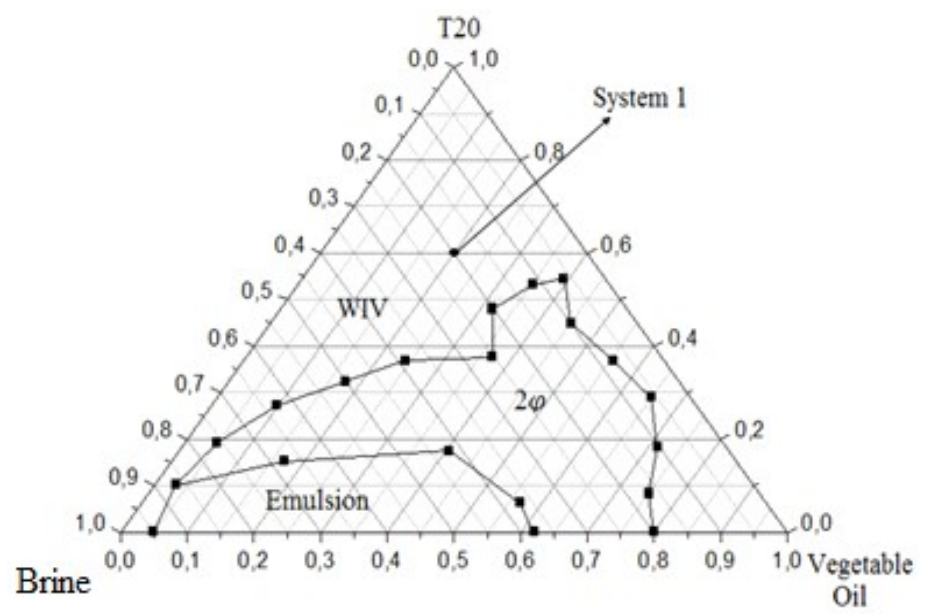

Figure 2: Phase diagram composed of brine, vegetable oil and T 20 (System 1). 


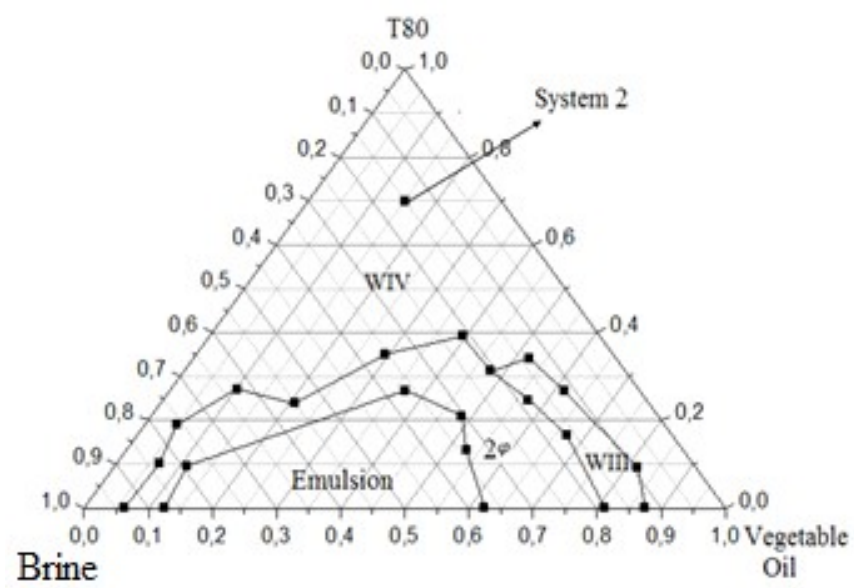

Figure 3: Phase diagram composed of brine, vegetable oil and T 80 (System 2).

According diagrams, was observed that microemulsion region for T80 is little high when compared with the T20. This effect may have been due to the difference between the HLB values of surfactants studied, 15 for T80 and 16.7 for T20, since the hydrophilic and lipophilic character of the surfactant determines its specific characteristics. The HLB was introduced by Griffin (1949) in order to quantify the hydrophilic and lipophilic (hydrophobic) characteristics of a molecule in solution, ie it is an attempt to determinate the effects of the contributions of the polar and nonpolar parts in the structure of the molecule. Although both have hydrophilic character, T80 by having the lower HLB than that of T20 gave a somewhat higher solubility of the oily phase and consequently a microemulsion region slightly larger.

\subsection{Rheological behavior}

According Rossi et al. (2007), the rheology is one of the important physical properties to analyze change the behavior of the formation of a microemulsion. In order to study the rheological behavior of microemulsions, two compositions were chosen, approximately equals, as shown in Table 1. The difference between the composition of T20 and T80, were related with the price of the surfactant. However, this work aimed to use the microemulsion in the WIV region.

Table 1: Compositions of microemulsions.

\begin{tabular}{|c|c|c|c|}
\hline Systems & Surfactant (wt.\%) & Oil (wt.\%) & $\begin{array}{c}\text { Brine } \\
\text { (wt.\%) }\end{array}$ \\
\hline 1 & 60 & 20 & 20 \\
\hline 2 & 70 & 15 & 15 \\
\hline
\end{tabular}

Some microemulsions were used for EOR, and the viscosity is an important property to ensure the sweep efficiency and thereby increase the oil recovery factor (Santanna et al., 2009; Santanna et al., 2013; Bera et al., 2014). The fluids used in the oil industry are not always Newtonian, in most cases, are non-Newtonian fluids that exhibit viscoelastic characteristics, depending on the shear rate to which they are submitted. It was observed that the 
microemulsions studied showed behavior of a non-Newtonian fluid, having better fit to the Herschel-Buckley model (Figures 4 and 5).

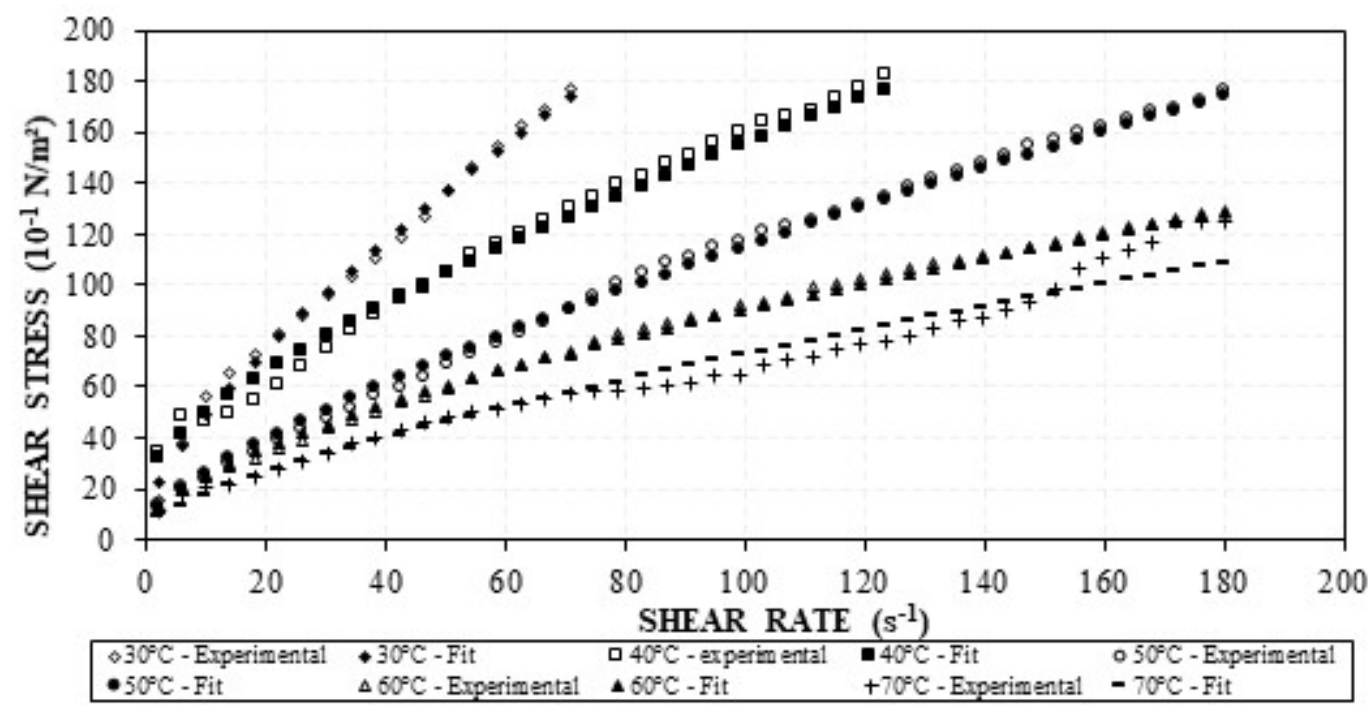

Figure 4: Rheological data for system 1.

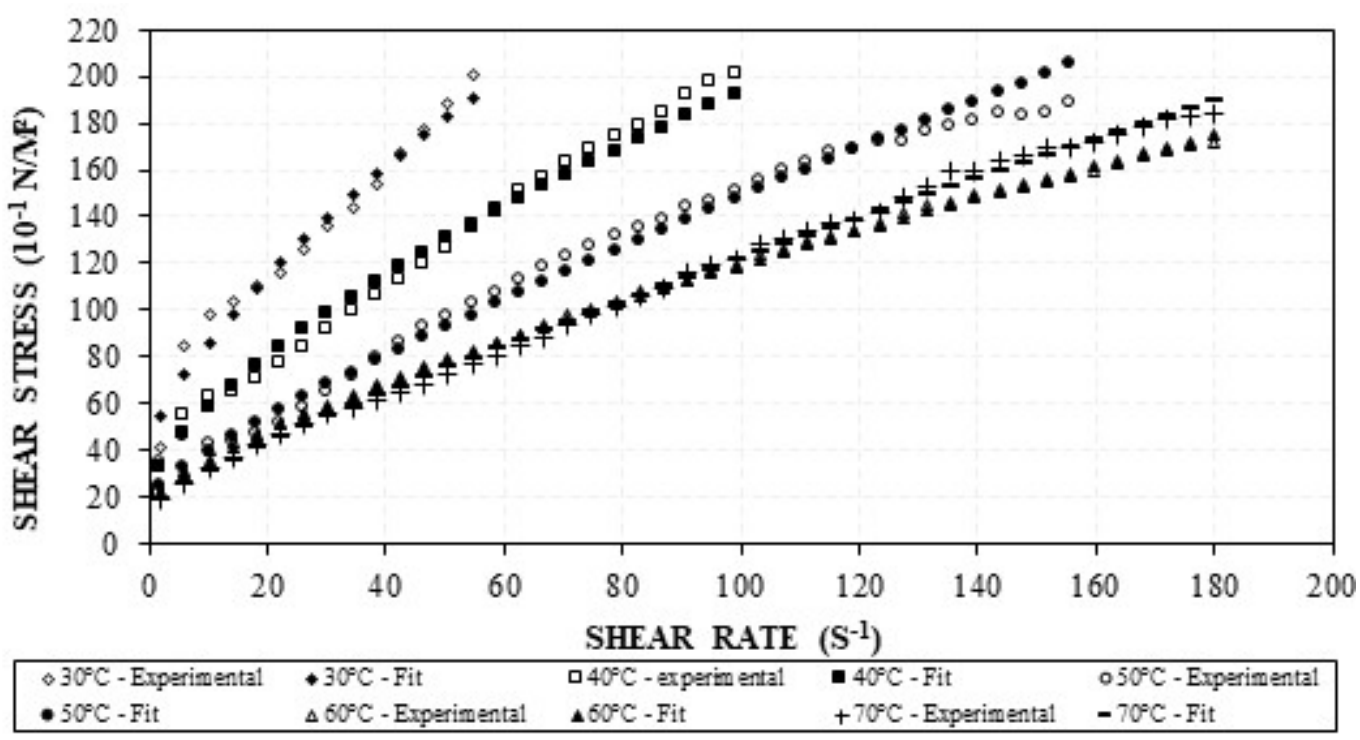

Figure 5: Rheological data for system 2.

The Herschel-Buckley, also known as power fluid with yield stress, have three rheological parameters: 0 , initial yield stress $\left(\mathrm{N} / \mathrm{m}^{2}\right)$; $\mathrm{n}$, flow behavior index (no dimensional); and, $\mathrm{K}$, consistency index (N.s/m²) Equation (1).

$$
\tau_{\mathrm{yx}}=\tau_{0}+\mathrm{K}\left(\frac{\partial \mathrm{u}_{\mathrm{x}}}{\partial \mathrm{y}}\right)^{\mathrm{n}}
$$

In System 1 (Figure 4), was observed that, at temperatures from 30 to $60^{\circ} \mathrm{C}$, satisfactory fit was obtained to Herschel-Buckley model $\left(R^{2}=99.7 \%\right)$. At temperature of $70^{\circ} \mathrm{C}$, was not obtained high level of confidence, however, between the models studied, it was possible to classify as power fluid with initial yield stress.

In System 2 (Figure 5), at temperatures from 40 to $70^{\circ} \mathrm{C}$, the best fit was obtained to Herschel-Buckley model $\left(R^{2}=98.8 \%\right)$, it can be checked by viscosity as a function of shear rate 
(Figure 7). At $30^{\circ} \mathrm{C}$, it was not obtained a satisfactory fit of experimental data, however, of the models studied, Herschel-Buckley's model showed the best level of confidence $\left(R^{2}=97.1 \%\right)$.

Table 2 shows the parameters of the Herschel-Buckley model for the two systems studied. It is noted that the system 2 presented to values initial yield stress ( $\left.t_{0}\right)$ higher than the system 1 , because the molecular weight of T80 is greater than T20, thereby requiring a larger initial yield stress $\left(t_{0}\right)$ for to flow. It is also observed that the values of $n$ (flow behavior index) are lower than 1 $(n<1)$ for both systems at all temperatures studied, showing pseudoplasticity these systems.

Table 2: Parameter's Herschel-Buckley.

\begin{tabular}{|c|c|c|c|c|}
\hline & Temperature & $\mathrm{t}_{0}\left(10^{-1} \mathrm{~N} . \mathrm{s} / \mathrm{m}^{2}\right)$ & $\mathrm{n}$ & $\mathrm{k}\left(10^{-1} \mathrm{~N} . \mathrm{s} / \mathrm{m}^{2}\right)$ \\
\hline \multirow{5}{*}{ System 1 } & $30^{\circ} \mathrm{C}$ & 11 & 0.75 & 6.74 \\
\cline { 2 - 5 } & $40^{\circ} \mathrm{C}$ & 24 & 0.72 & 4.77 \\
\cline { 2 - 5 } & $50^{\circ} \mathrm{C}$ & 6 & 0.74 & 3.52 \\
\cline { 2 - 5 } & $60^{\circ} \mathrm{C}$ & 5 & 0.63 & 4.76 \\
\hline \multirow{5}{*}{ System 2 } & $70^{\circ} \mathrm{C}$ & 5 & 0.73 & 2.36 \\
\cline { 2 - 5 } & $30^{\circ} \mathrm{C}$ & 40 & 0.70 & 9.15 \\
\cline { 2 - 5 } & $40^{\circ} \mathrm{C}$ & 20 & 0.66 & 8.18 \\
\cline { 2 - 5 } & $50^{\circ} \mathrm{C}$ & 20 & 0.83 & 2.83 \\
\cline { 2 - 5 } & $60^{\circ} \mathrm{C}$ & 17 & 0.73 & 3.49 \\
\cline { 2 - 5 } & $70^{\circ} \mathrm{C}$ & 15 & 0.83 & 2.31 \\
\hline
\end{tabular}

Knowing that the shear rate and temperature are factors that affect the viscosity, it was observed, Figures 6 and 7, which viscosity decreases with increase of the temperature.

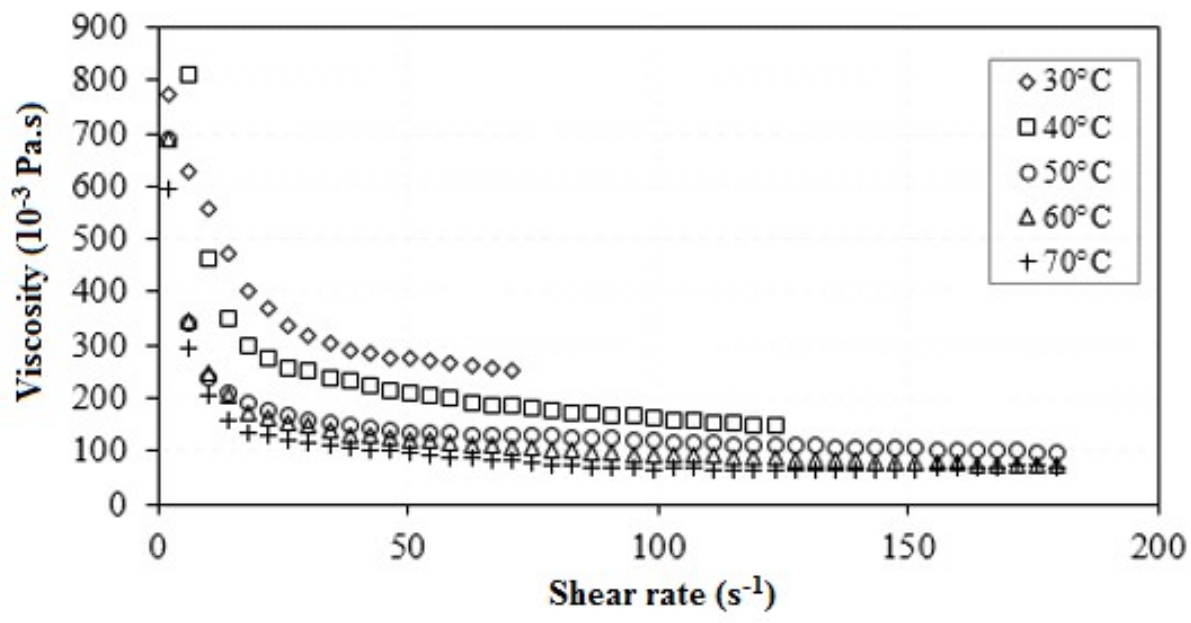

Figure 6: Viscosity of the microemulsion (system 1) as a function of shear rate. 


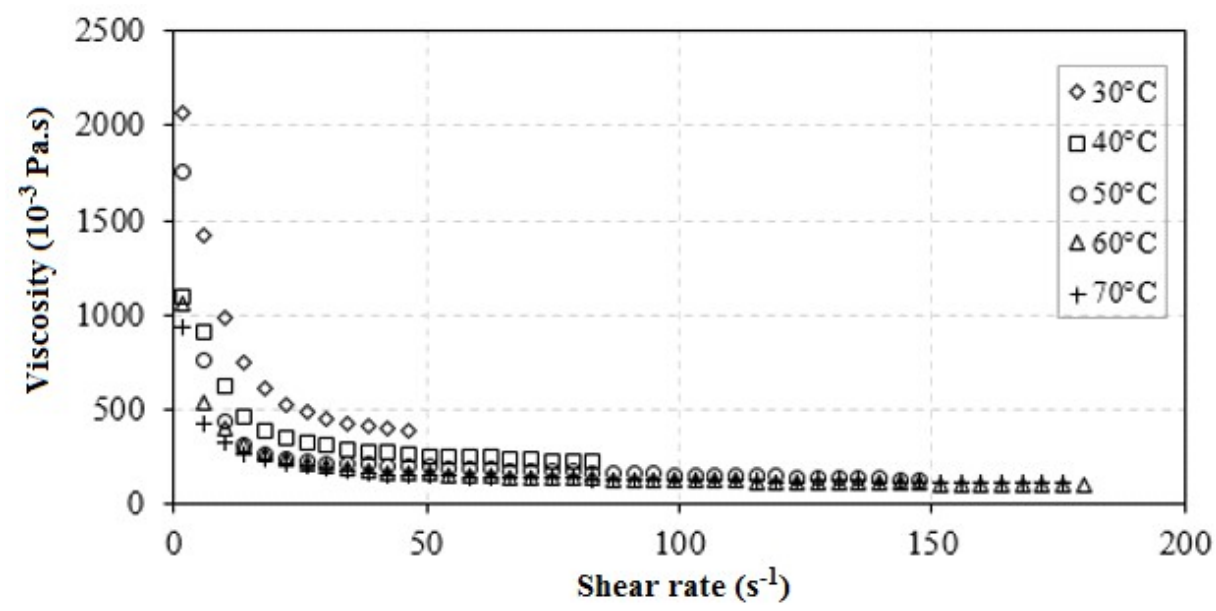

Figure 7: Viscosity of the microemulsion (system 2) as a function of shear rate.

In high temperature, occurs the uncontrolled movement of the molecules that increase the distance between adjacent micelles, decreasing the volume of the micelles and, consequently, reducing its viscosity (Baruah et al., 2015).

\subsection{Cloud point}

The cloud point data (Table 3 ) indicated that system 2 has turbidity temperature, $72{ }^{\circ} \mathrm{C}$, higher than system $1,53{ }^{\circ} \mathrm{C}$. The cloud point is an important property of surfactant/microemulsion, since, at this point, some microemulsion lose their structure and rheological characteristics. This difference in cloud point of microemulsion could be related due a change in micelle morphology.

Table 3: Data of cloud point for systems studied.

\begin{tabular}{|c|c|}
\hline Systems & Temperature $\left({ }^{\circ} \mathrm{C}\right)$ \\
\hline 1 & $53^{\circ} \mathrm{C}$ \\
\hline 2 & $72{ }^{\circ} \mathrm{C}$ \\
\hline
\end{tabular}

\section{CONCLUSION}

In this work, microemulsion systems were evaluated by rheological behavior in different temperatures. The main conclusions were that:

- The systems selected in microemulsion regions were classified as non-Newtonian fluids, according with Herschel-Buckley's model; and it has been observed that the viscosity of the microemulsion decreases with increasing shear rate and temperature;

- This behavior is desirable to formulate, specifically, drilling fluids, by increasing of flow rate of fluid within the drill pipe, and the shear rate, and hence a decrease in the viscosity of the fluid, that is needed to flow easily into the column; 
- Microemulsions developed also can be used to increase the oil recovery factor, since they have viscosity and behavior suitable to obtain good sweep and displacement efficiencies;

- Finally, both systems can be used, but specifically the system 2 is most indicated, because it has a cloud point higher than the temperature of the oil wells $\left(\sim 55^{\circ} \mathrm{C}\right)$, and this ensures that this microemulsion system will work in satisfactory conditions without losing its properties.

\section{REFERENCES}

Baruah, A., Pathak, A. K, \& Ojha, K. (2015). Phase behavior and thermodynamic properties of lamellar liquid crystal developed for viscoelastic surfactant based fracturing fluid. Chemical Engineering Science, 131, 146-154. doi: 10.1016/j.ces.2015.03.067

Bera, A., Kumar, T., Ojha, K., \& Mandal, A. (2014) Screening of micromemulsion properties for application in enhanced oil recovery. Fuel, 121, 198-207. doi: 10.1016/j.fuel.2013.12.051

Daltin, D. (2011). Tensoativos: química, propriedades e aplicações. São Paulo: Editora Blucher.

Karambeige, M. S., Nasiri, M., Asl, A. H., \& Emadi, M. A. (2016). Enhanced oil recovery in high temperature carbonates using microemulsions formulated with a new hydrophobic component. Journal of industrial and engineering chemistry, 39, 136 - 148. doi: 10.1016/j.jiec.2016.05.020

Lange, K. R. (1999). Surfactants: A Practical Handbook. Munich: Hanser.

Lee, K. L. (2011). Applications and Use of Microemulsions. Cornell University Library. arXiv:1108.2794 online archive.

Quintero, L., Jones, T., Clark, D. E., \& Twynam, A. J. (2007). NAF filter cake removal using microemulsion technology. European Formation Damage Conference Held in Scheveningen, 30 May - 1 June, Netherlands. doi: 10.2118/107499-MS

Quintero, L., Jones, T., Clark, D. E., \& Schwertner, D. (2009). Cases History studies of production enhancement in cased hole wells using microemulsion fluids. European Formation Damage Conference Held in Scheveningen, 27-29 May, Netherlands. doi: 10.2118/121926-MS

Quintero, L., Jones, T. A., \& Pietrangeli, G. (2011). Phase boundaries of microemulsion systems help to increase productivity. European Formation Damage Conference, 7-10 June, Netherlands. doi: 10.2118/144209-MS

Reed, R. L., \& Healy., R. N. (1977). Some physicochemical aspects of microemulsion flooding: a review. Improved oil recovery by surfactant and polymer flooding, $383-437$. doi: 10.1016/B978-0-12-641750-0.50017-7

Rossi, C. G. F. T., Dantas, T. N. C., Dantas Neto, A. A., \& Maciel, M. A. M. (2007). Microemulsões: uma abordagem básica e perspectivas para aplicabilidade industrial. Revista Universidade Rural: Ciências Exatas e da Terra, 26, 45 - 66.

Santanna, V. C., Curbelo, F. D. S., Castro Dantas, T. F., Dantas Neto, A. A., Albuquerque, H. S., Garnica, A. I. C. (2009). Microemulsion flooding for enhanced oil recovery. Journal of Petroleum Science and Engineering, 66, 117-120. doi: 10.1016/j.petrol.2009.01.009 
Santanna, V. C., Silva, A. C. M., Lopes, H. M., Sampaio Neto, F. A. (2013). Microemulsion flow in porous medium for enhanced oil recovery. Journal of Petroleum Science and Engineering, 105, 116-120. doi: 10.1016/j.petrol.2013.03.015

Winsor, P. A. (1954). Solvent Properties of Amphiphilic Compounds. Butterworths Scientific Publ. Ltd. London. 